Mercator, Fortaleza, v. 17, e17028, 2018.

DOI: https://doi.org/10.4215/rm2018.e17028

ISSN: $1984-2201$

Copyright @ 2002, Universidade Federal do Ceará

\title{
RECONFIGURATION OF THE LANDSCAPE IN THE AMAZONIAN SAVANNAS
}

\author{
SILVA, Gladis de Fatima Nunes da; ${ }^{\text {a* }}$ OLIVEIRA, Ivanilton José de; ${ }^{\mathrm{b}}$
}

(a) PhD in Geography. Professor State University Roraima (UERR), Boa Vista (RR), Brazil. ORCID ID: https://orcid.org/0000-0002-7521-2281. CURRICULUM LATTES: http://lattes.cnpq.br/7248682132263965

(b) PhD in Geography. Professor Federal University Goias (UFG), Goiânia (GO), Brazil. ORCID ID: https://orcid.org/0000-0002-2718-6947. CURRICULUM LATTES: http://lattes.cnpq.br/4172719252263913

\section{(*) CORRESPONDING AUTHOR}

Address: UERR - Rua 7 de Setembro, 231, Canarinho, CEP: 69306 530, Boa Vista - RR, Brazil. Tel: (+55 62) 991305120. E-mail: gladisilva@hotmail.com

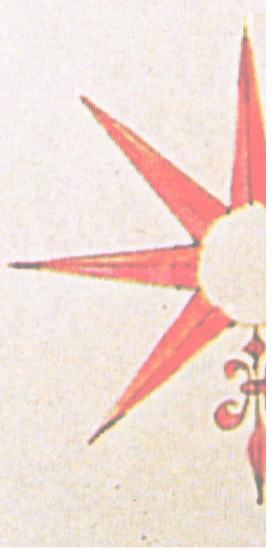

\begin{abstract}
The occupation process of the savannahs in Roraima which is reflected in an outstanding way in the modification of its landscapes. This study is aimed at analyzing the expansion of agricultural activities and the changes to the landscapes of the savannas in the municipality of Boa Vista (RR), known by the local name "Lavrado", between the years 2000 and 2014. To reach the objectives, the methodology of Environmental Analysis by Geoprocessing, was adopted, with diagnostic procedures such as inventories, signatures, and environmental assessments. The results indicated that intensification of the use and modification of land cover, occurring in the production of grains (soybean), is occurring. The historical process of occupation and intensification of use occurred as a result of the actions of the State, like the measures of the state government, which guide its strategies in the strengthening of agriculture and livestock. In this scenario, the conversion of the savannas became strategic to the productive process, like that which occurred in the Cerrado biome of Central Brazil, mainly during the 1970s.
\end{abstract}

Keywords: Cerrado; Landscape; Agricultural; Change of use and land cover.

\section{RESUMO / RESUMEN}

\section{RECONFIGURAÇ̃̃O DA PAISAGEM NAS SAVANAS DA AMAZÔNIA}

O processo de ocupação das savanas em Roraima tem refletido de forma marcante na modificação de suas paisagens. Neste estudo buscou-se analisar a expansão de atividades agropecuárias e as mudanças nas paisagens das savanas no município de Boa Vista (RR), conhecidas pela denominação local de "Lavrado", entre os anos de 2000 e 2014. Para atingir os objetivos, adotou-se a metodologia de Análise Ambiental por Geoprocessamento, com procedimentos de diagnóstico, como os inventários, assinaturas e avaliações ambientais. Os resultados indicaram que está ocorrendo intensificação do uso e modificação da cobertura da terra, ligadas à produção de grãos (soja). O processo histórico de ocupação e intensificação do uso ocorreu a partir das ações do Estado, como as medidas do governo estadual, que pautam suas estratégias no fortalecimento da agropecuária. Neste cenário, a conversão das savanas tornou-se estratégica ao processo produtivo, de forma semelhante ao ocorrido no bioma Cerrado do Brasil Central, principalmente a partir da década de 1970 .

Palavras chaves: Cerrado; Paisagem; Agropecuária; Mudança de uso e cobertura da terra.

\section{RECONFIGURACIÓN DEL PAISAJE EN LAS SABANAS DE LA AMAZONIA}

El proceso de ocupación de las sabanas en Roraima ha reflejado de forma marcada en la modificación de sus paisajes. En este estudio se buscó analizar la expansión de actividades agropecuarias y los cambios en los paisajes de las sabanas en el municipio de Boa Vista (RR), conocidas por la denominación local de "Labrado", entre los años 2000 y 2014. Para alcanzar los objetivos, se utilizó la metodología de Análisis Ambiental por Geoprocesamiento, con procedimientos de diagnóstico, como los inventarios, firmas y evaluaciones ambientales. Los resultados indicaron que está ocurriendo intensificación del uso y modificación de la cobertura de la tierra, ligadas a la producción de granos (soja). El proceso histórico de ocupación e intensificación del uso ocurrió a partir de las acciones del Estado, como las medidas del gobierno estadual, que pautan sus estrategias en el fortalecimiento de la agropecuaria. En este escenario, la conversión de las sabanas se tornó estratégica al proceso productivo, de forma semejante al ocurrido en el bioma Cerrado do Brasil Central, principalmente a partir de la década de 1970 .

Palabras-clave: Cerrado, paisaje, agropecuaria, cambio de uso y cobertura de la tierra 


\section{INTRODUCTION}

In the girdle of maximum biological diversity on the planet, the Amazonia stands out for the extraordinary continuity of its forests, for the greatness of its main hydrographic network and for the variations of its ecosystems at regional and altitude level (AB'SÁBER, 2003). The Amazon biome covers an area of $4.196 .943 \mathrm{~km} 2$ (IBGE, 2004) of the national territory; of this total, approximately $200.000 \mathrm{~km} 2$ are fields and savannas that are dispersed in isolation (enclaves) and not isolated (peripheral) along the forest's continuum under different types of climates, edaphic actors, relief and anthropogenic disturbances (SANAIOTTI et al., 2002; SANTOS et al., 2007).

The unconnected spots of cerrados, dispersed in the rainforest in the states of Amapá, Amazonas, Pará, and Roraima, are known as Amazonian savannas (PRANCE, 1996). Its physiognomy is similar to that of the Cerrado of Central Brazil, with a grassy stratum and variable density of trees and shrubs.

The state of Roraima, located in the extreme north of the Brazilian Amazon, has the largest continuous area of savannahs in the Amazon biome, occupying an area estimated at $43.000 \mathrm{~km} 2$ (BARBOSA; CAMPOS, 2011). The savannas are distributed predominantly in the northeastern portion of the state and are part of the Rio Branco-Rupununi landscaped complex, established between Brazil, Guyana, and Venezuela.

The term Lavrado, a local name given to the savannas in Roraima, according to Vanzolini and Carvalho (1991), is derived from the archaic Portuguese language, but can still be found in modern dictionaries, meaning a place absent of trees - which is consistent with the savanna landscape of Roraima, dominated by grasslands. The historical process of anthropic occupation in Roraima carried out by means of managed or spontaneous colonization, triggered ecological implications in different ecosystems, considering the use of traditional soil preparation and management practices for the implantation of agricultural crops and pastures.

The conversion of savannas to anthropic uses for economic activities intensified in the late 1970s, as a result of the establishment or expansion of road hubs that served as support for agricultural and livestock expansion projects, associated with local population growth (BARBOSA; CAMPOS, 2011).

Currently, most of the large expansion plans for the agribusiness sector (sugar cane, Soy, forestry etc.) are found in the Savannah region of Brazil, which triggered a wide modification of the geoecological conditions of the landscape. As a category of geographic analysis, the landscape presents a complex multi-dimensionality, which makes possible the understanding of the relations between humans and the modifications in the space where they live.

Thus, to understand the dynamics of the landscape of the savannas of Roraima today, it is relevant to know the changes in the use and cover of the land, which includes the expansion of agriculture, which has been taking place since the late 1970s. To accompany the dynamics of the landscape, the use of geotechnologies has become essential, especially the remote sensing products, as instrumental support for mapping and recording of the changes in land use and land cover, with the spatialization produced, guide the process of decision making, formulation and implementation of public policies.

In this context, the present study aimed to investigate the spatial-temporal dynamics of land use and land cover in the municipality of Boa Vista (RR), between the years 2000 and 2014. This space-time frame was considered as a representative scenario of the recent agricultural expansion process and to gather intrinsic characteristics of the strategies used in the process of occupation of the Amazonian savannas. 


\section{MATERIALS AND METHODS}

The work was based on the methodology of Environmental Analysis by Geoprocessing, proposed by Xavier-da-Silva and Carvalho-Filho (1993), with diagnostic procedures, such as inventories, signatures and environmental assessments.

The first stage involved working with secondary data, and consisted of bibliographical and documentary research, based on theoretical review, held in the indexes of journals, public library websites and digital these and dissertation databases, in search of articles, books, dissertations and theses that addressed the historical process of occupation in the state of Roraima. Concomitantly, the compilation of cartographic databases in the SIG environment, especially those related to the physical environment, available in digital format at the internet portals of public agencies, such as the IBGE-RR and the Secretary of Planning and Development of the State of Roraima (SEPLAN-RR). The second stage was dedicated to working with primary sources. The methodological proce- dures consisted of, at first, in the acquisition of Remote Sensing data corresponding to the digital images of the TM / Landsat-5 sensor, referring to the year 2000, and OLS / Landsat 8, corresponding to the year 2014. The images were obtained from the INPE image catalog (available at: $<\mathrm{http}: /$ www.inpe. br $>$ ) and on the website Earth Explorer ( $<$ http://earthexplorer.usgs.gov $>)$. The main characteristics of this data are detailed in Table 1.

Table 1 - Characteristics of the orbital images used

\begin{tabular}{c|c|c|c|c}
\hline Satellite/ Sensor & Órbit/Point & Spectrum bands & Spatial resolution $(\mathrm{m})$ & Date \\
\hline Landsat-5/ TM & $232 / 58$ & $3,4,5$ & $30 \times 30$ & $01-04-2000$ \\
\hline Landsat 8/ OLS & $232 / 58$ & $6,5,4$ & $30 \times 30$ & $07-03-2014$ \\
\hline
\end{tabular}

In the GIS environment, specifically using the ArcGIS 10.1 software, the processing of the digital images consisted of the operation of pre-processing of geometric correction, through the image-image registry, used to adjust the rows and columns of the images to their corresponding geographical location. For this, the GeoCover mosaic was used, obtained from the website Global Land Cover Facility (GLCF) of National Aeronautics and Space Administration - Nasa ( $<$ https:// zulu.ssc.nasa.gov/mrsid/>).

The geometric correction was done through the application of polynomial transformation of $3 \mathrm{rd}$ degree, with the collection of 30 control points for the study area. In the step of acquiring control points via the screen, it was considered the regular distribution of these throughout the study area, besides the minimum number required for the polynomial transformation.

For the resampling of the pixels of the image, the cubic convolution method was used. The next step consisted of digital classification processing, based on Mahalanobis's distance-supervised segmentation and classification operations, in which it is taken as a reference, for each class, a point in the multidimensional space defined by the statistical mean of each spectral band considered.

Training samples were selected for land use and land cover classes, by means of visual analysis of the features of land cover and use, based on the knowledge of the field and field information, collected in May 2014. Then a random stratified sampling of the pixels was performed, with selected samples of each type of land cover and use.

In this way, five classes were broken down: forestry formation, such as Riparian forests or Moriche palm groves along watercourses and "islands" of forests; water bodies, characterized by rivers, lakes and other bodies of water; savannah or pastoral formation, corresponding to areas covered by savanna vegetation, typically grassy; agriculture, concerning the areas with the occurrence of agricultural activities, pasture or cultivated forest formations; urban area, characterized by the presence of urban concentration. The key to understanding, elaborated in the development of this study, was based on some concepts of the land use manual of the Brazilian Institute of Geography and Statistics (IBGE, 2006). After sorting the images, the data was transformed into vectors, which 
passed through a new stage of visual inspection polygon to polygon, generating as a final product two thematic images that allowed the space-time identification of the changes occurred in the forms of land cover and use in the municipality of Boa Vista (RR). Finally, the area occupied by each class in the GIS environment was quantified..

\section{RESULTS AND DISCUSSION}

\section{DEFINITION OF THE STUDY ÁREA}

The municipal of Boa Vista is located in the central eastern portion of the state of Roraima and occupies an area of $5,687 \mathrm{~km}^{2}$, which has an estimated population of 332,020 (IBGE, 2017). From the point of view of geological aspects, the municipality is embedded in the large con- served planing surface of the state, and comprises mainly, sedimentary soils of the fluvial-alluvial environment of the Boa Vista Formation (Figure 1). This formation, in the interpretation of Wankler, Evangelista, and Sander (2012), is considered of tertiary age and of fluvio-alluvial origin, consisting of intercalations of loamy sediments, silty and sandy, from fine to coarse granulation, with sediments that cover part of the center-east sector of the state of Roraima.

In relation to geomorphological features, the landscape in the study area comprises the morpho-structural units called Depression Boa Vista, Patamar do Médio Uraricoera, Residencial Plateaus of Roraima, Pediplane Rio Branco-Rio Negro and Amazonian flat land (Figure 2). According to data from IBGE (2005), the Depression Boa Vista, the largest geomorphological unit in extension in the municipality, corresponds to an accumulation model (Agradation) and is characterized by being an extensive flat region, with average altitude ranging from 80 to 110 meters, without great restrictions to mechanization.

The pedology of the study area is represented by the Oxisols, Ultisols, and Entisols. However, the most extensive soil class is the dystrophic Yellow Oxisol (LAd), which corresponds to 85\% of

the total of the municipality (Figure 3). The occurrence of dystrophic Yellow Oxisols (LAd) in the central areas of the state is related to the sandy-clay sediments of the Boa Vista formation dating from the late Tertiary and early Qua- ternary periods (Plio-Pleistocene), elaborated from alternating cycles of humid and dry climates, under savanna-type vegetation cover (VALE JR .; SCHAEFER, 2010, p. 20).

The vegetation of the study area presents as a mosaic, predominating savannic phytophysiognomies, such as Gramineous-Woody Savannah $(\mathrm{Sg})$. However, forest features are also part of the Lavrado landscape in the municipality and are characterized mainly by the Alluvial Ombrophylous Forest, Seasonal Forest, Seasonal Forest / Dense Ombrophylous Forest and Grass areas (semideciduous enclaves), and Gallery Forest (Figure 4). According to the vegetation technical manual (IBGE, 2012), in the physiognomy of Grassy-Shrubland Savanna (Sg), when natural, the grass is interspersed by rickety woody plants, that occupy extensive areas dominated by hemicryptophytes and that, little by little, when they are ma- naged through fire or grazing, are replaced by geophytes, which are distinguished by their presence of subterranean stalks, therefore, more resistant to cattle trampling and fire.

The Lavrado in the municipality also includes a diversity of forest physiognomies that occur in areas with more fertile soils or with greater availability of water. The Gallery Forests accompany most of the rivers and streams and are marked by the presence of the buriti palm (Mauritia flexuosa), forming trails that stand out in the landscape in open environments of adjacent savannas. 

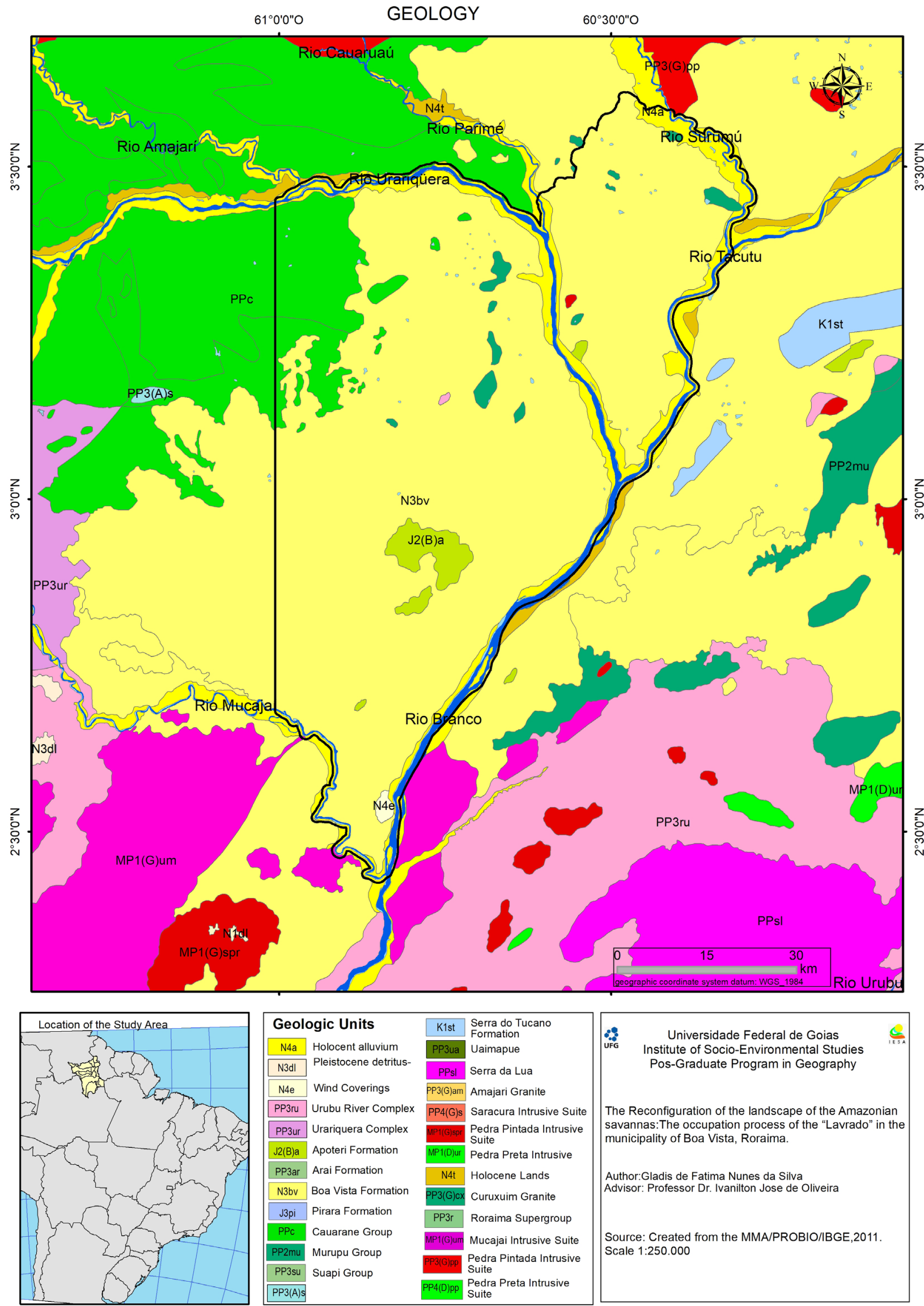

Figure 1 - Geological map of the municipality of Boa Vista (RR) and surroundings 


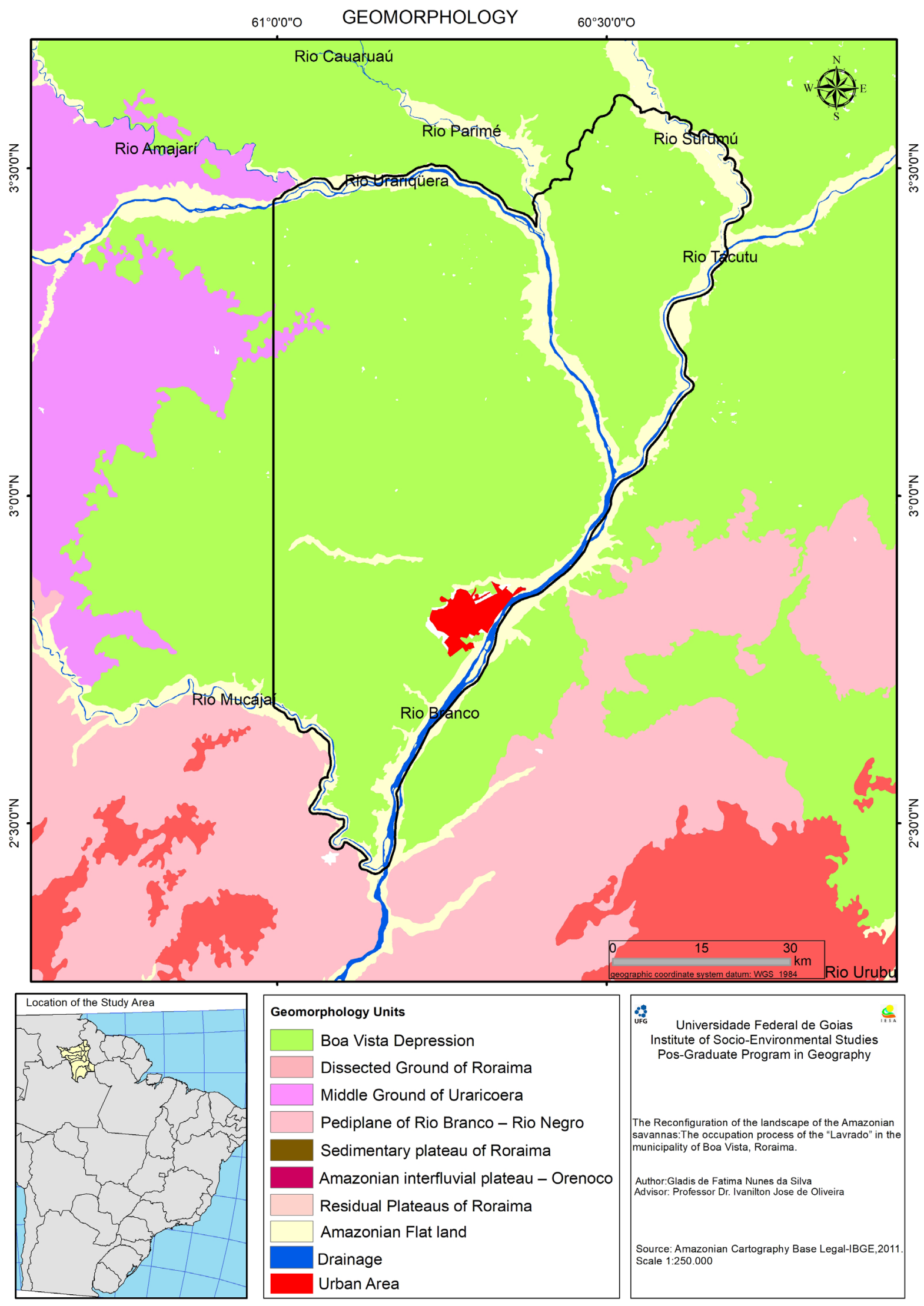

Figure 2 - Map of the Geomorphological Units of the Municipality of Boa Vista (RR) and surroundings 


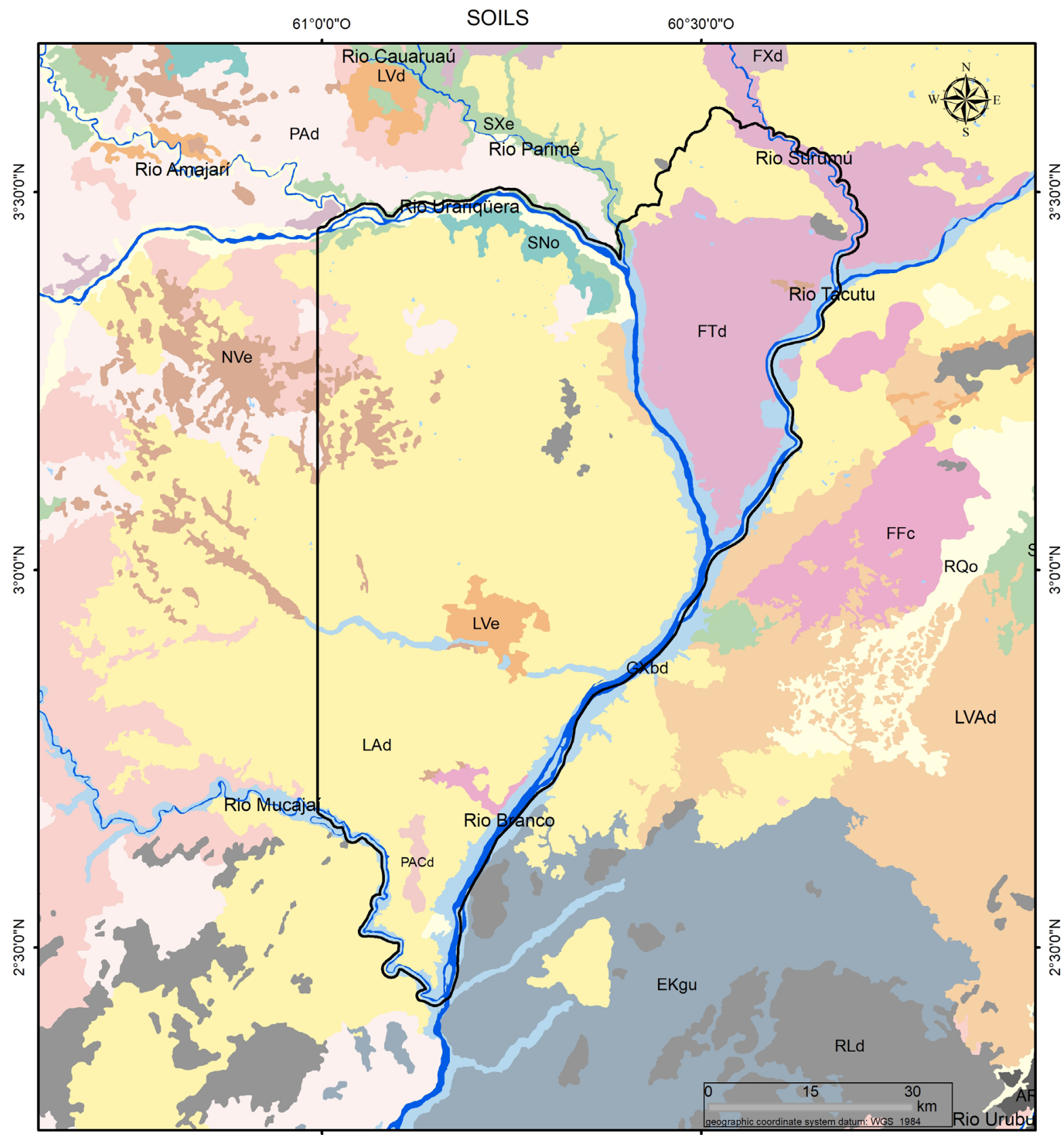

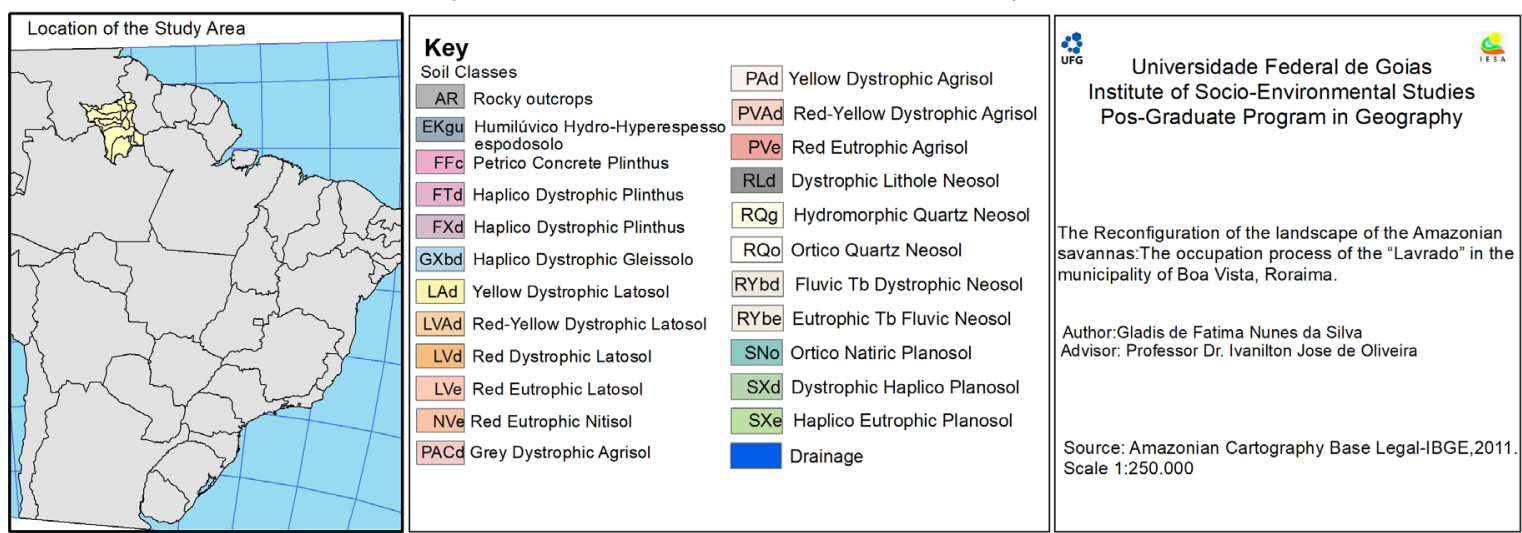

Figure 3 - Map of soils of the municipality of Boa Vista (RR) and surroundings 


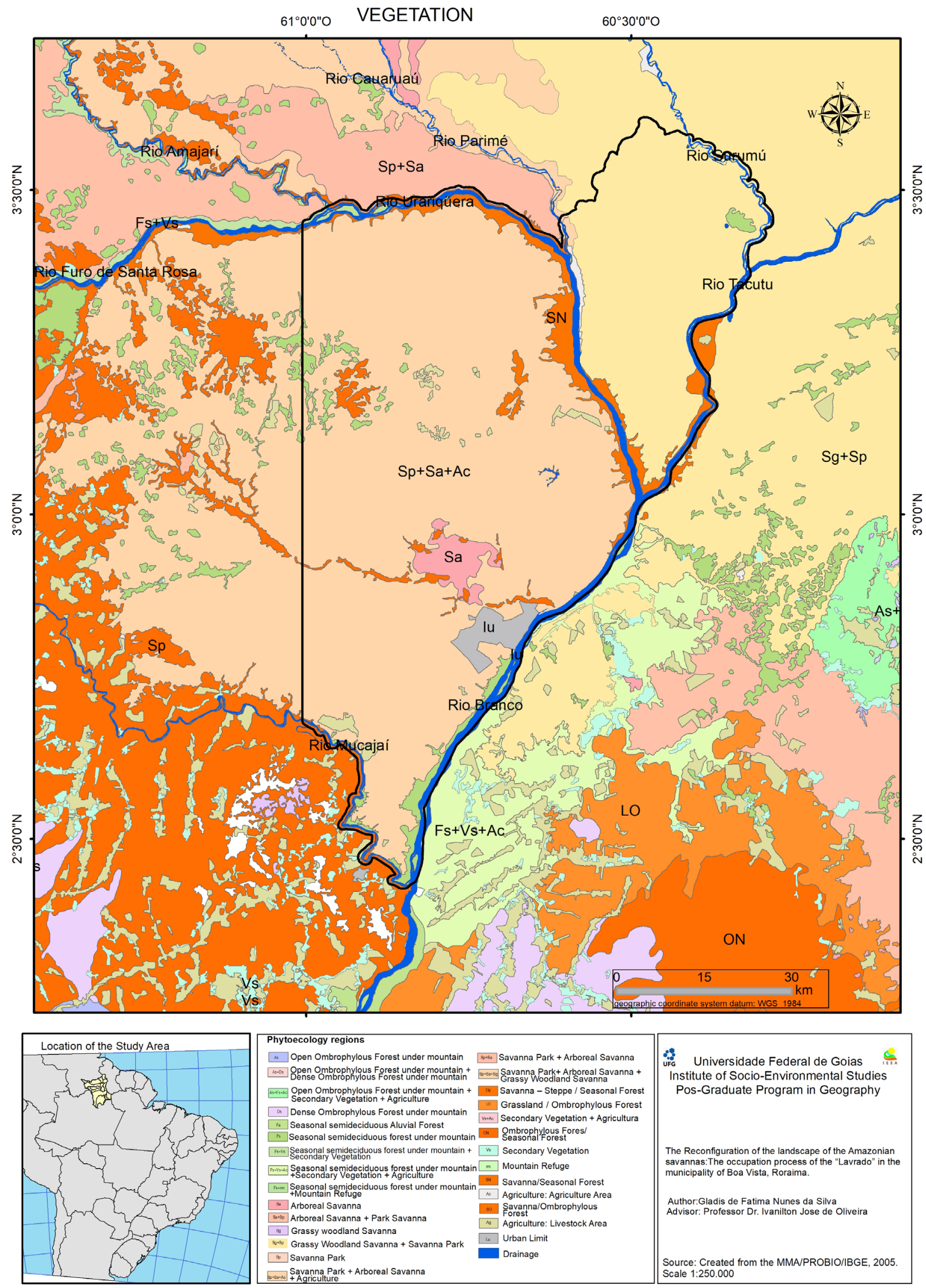

Figure 4 - Map of the vegetation of the municipality of Boa Vista (RR) and surroundings 


\section{CONTEXTUALIZATION OF THE SAVANNA OCCUPATION PROCESS IN RORAIMA}

The process of anthropic occupation of the Rio Branco valley, the present state of Roraima, originated from the European colonization, which occurred in the second half of the eighteenth century. The Portuguese colonizers achieved an effective dominion of this region by means of the construction of Fort San Joaquim and the installation of three state farms, destined to have livestock activity.

At this juncture, savanna/grassland areas become the first to be occupied due to their geographical position and the peculiar physiographic characteristics, distinct from the forested areas of the Amazon. Cattle ranching in the savannas of the Rio Branco valley presented a long virtuous cycle of development, which extended from the late eighteenth century to the end of the nineteenth century, constituting the main economic activity of the region. However, at the beginning of the twentieth century, cattle ranching declined due to the limitations imposed on commercialization resulting from the crisis of the extraction of rubber in the Amazon, starting in 1920 (DINIZ, 1998). During 'Getulio Vargas' government (1930-1945), different strategies were established to stimulate perennial settlement and economic development. Despite structural changes, Roraima remained sparsely populated and economically isolated until the early 1970s. Expressive changes in the area of Roraima occurred within the scope of state intervention in the Amazon, inserted in the context of the geopolitical project of national integration and exploitation of natural resources, starting in the 1970 s.

In 1975 POLORORAIMA was established, linked to the POLOAMAZÔNIA Poles Program, which made possible the construction of BR-174 (Manaus-Boa Vista-Venezuela) and part of BR210 - known as Perimetral Norte, designed to interconnect Amazonas to Roraima, Pará, and Amapá. In the late 1970s and early 1980s, the Territory Government also began the phase of Directed Settlement Programs - PAD (BARBOSA, 1993b). With the implementation of the highways, the migration towards Roraima was amplified, ac- cording to Barbosa (1993b, p.184).

After the first stage of the great settlements, the intensification of the exploitation of mineral wealth in the late 1980s, as well as the transition from the Federal Territory of Roraima to a member state of the Federation (1988), are the factors that contributed to the attraction of the population towards Roraima. However, the mining activity was conducted illegally and the miners worked in areas of environmental preservation and indigenous reserves. The beginning of the 1990s was marked by the closure of illegal mines and the restriction of indigenous lands, which led to the slowing of migratory flows to the state, although there have been government programs for the recruitment of migrants in this decade.

Through this context, the state government has its strategies based on agriculture, as one of the vectors to reach economic and social development. As a result, savanna areas become strategic as state government policies and plans are focused on incorporating these areas into the productive process. Similar to the areas of the Cerrado of Central Brazil, a set of factors that involve the political, economic aspects associated with natural conditions contribute to the intensification of the agricultural occupation of savannahs in Roraima. Among the constraints is the fact that the landscapes of savannas are distributed in areas of flat relief, therefore, favorable to mechanization with the existence of a regular pluviometric regime, a large supply of water for irrigation, and greater light due to its geographical position. Another important factor is the creation of programs and fiscal incentives for agricultural enterprises by the state government, especially with incentives to produce grain (soybean) in savanna areas. In this context, livestock farming was initially the main factor of visible changes in the landscape of the study area, however, the use of land for crops is a recent method within Roraima. 


\section{LAND USE IN BOA VISTA IN THE YEAR 2000}

In 2000, the municipality of Boa Vista had 200,568 inhabitants (IBGE, 2000), which represented $65.4 \%$ of the population of the state of Roraima. Of these, 197,098 were residents of the city and 3,470 in the rural area. Despite the urbanization process and the inherent development of the services and commerce sectors, resulting from the housing of the public-administrative sector, the job creation is mainly carried out by the public sector. In this way, the productive structure of the municipality is based on the tertiary sector. Meanwhile, the agricultural sector of Boa Vista municipality exhibited an important component of the local economy during this decade, as a result of the closure of illegal mines in the state, responsible for the economic push in the last two decades.

In analyzing the spatial-temporal distribution pattern of land use and land cover classes in the municipality and the environmental planimetry (Figure 5 and Table 2), it can be observed that the anthropic activities in 2000 were incipient, since $4,746 \mathrm{~km} 2$ (equivalent to $83.6 \%$ of the area) still presented remnant vegetation cover, of grassland and savanna formations. The forest areas, especially the riparian forests, were less fragmented, occupying $646.2 \mathrm{~km} 2$, or $11.38 \%$ of the total area of the municipality.

However, since the 18th century, vast areas of Lavrado in the municipality were converted into natural pastures for the extensive breeding of cattle. According to Costa (2009), the native pastures of the Lavrado represented the main food source of the bovine herd. The use of fire for biomass renewal has also been and still is rooted in the cultural and economic logic among ranchers in the savannah areas.

In this sense, it is probable that the present landscapes of the savannas have some anthropic contribution, from the use of the earth, especially by the action of burning. According to Walter, Carvalho, and Ribeiro (2008, p.35), the burnings influence the distribution and floristic composition of the savannas, affecting the structures of the stretches of vegetation.

Over the years, fire has been the only management element and the great selector of native grass species in this ecosystem, being used up to three times a year, composing an important ecological factor of the region, but with highly reflective significant and negative effects on environmental liabilities arising from livestock activities (CORADIN, 1979).

It seems that in 2000, agricultural activities were not very significant in the municipality since the areas destined to agriculture corresponded to just over $50 \mathrm{~km}^{2}$, approximately $0.89 \%$ of the total area of Boa Vista. The agricultural areas were intended for the cultivation of irrigated rice and probably soy and corn. However, there are no statistics available from the IBGE regarding the planted area and soybean production for the municipality in the year 2000.

Rice cultivation in Roraima began in the 1980s, and the activity was made possible through a public policy of the Federal Government, with the National Program Várzeas Irrigáveis - PROVÁRZEAS, which presented as a guideline the exploitation of the existing floodplains in the then territory, aiming at the incorporation of new areas into the productive process. Initially, rainfed rice was produced, however, irrigation is currently predominant at the commercial level, and planting is carried out twice a year in the state.

Cordeiro (2005, p.170) points out that the floodplain areas, especially those located in savanna areas, have flat topography and facilities for mechanization and irrigation. Rice production in Roraima is favored by climatic aspects, especially sunshine, low thermal oscillation and water availability, which contribute significantly to the quantity and quality of rice produced in the region (CORDEIRO et al., 2010). The average production in 2008 oscillated between 5,000 and 7,000 kg/ ha (MOURÃO, 2008, p.106). According to data from the Municipal Agricultural Research - IBGE (2000), the rice plantations in the municipality occupied, in 2000, an area of 1,614 hectares, distributed mainly on the banks of the Branco River. 


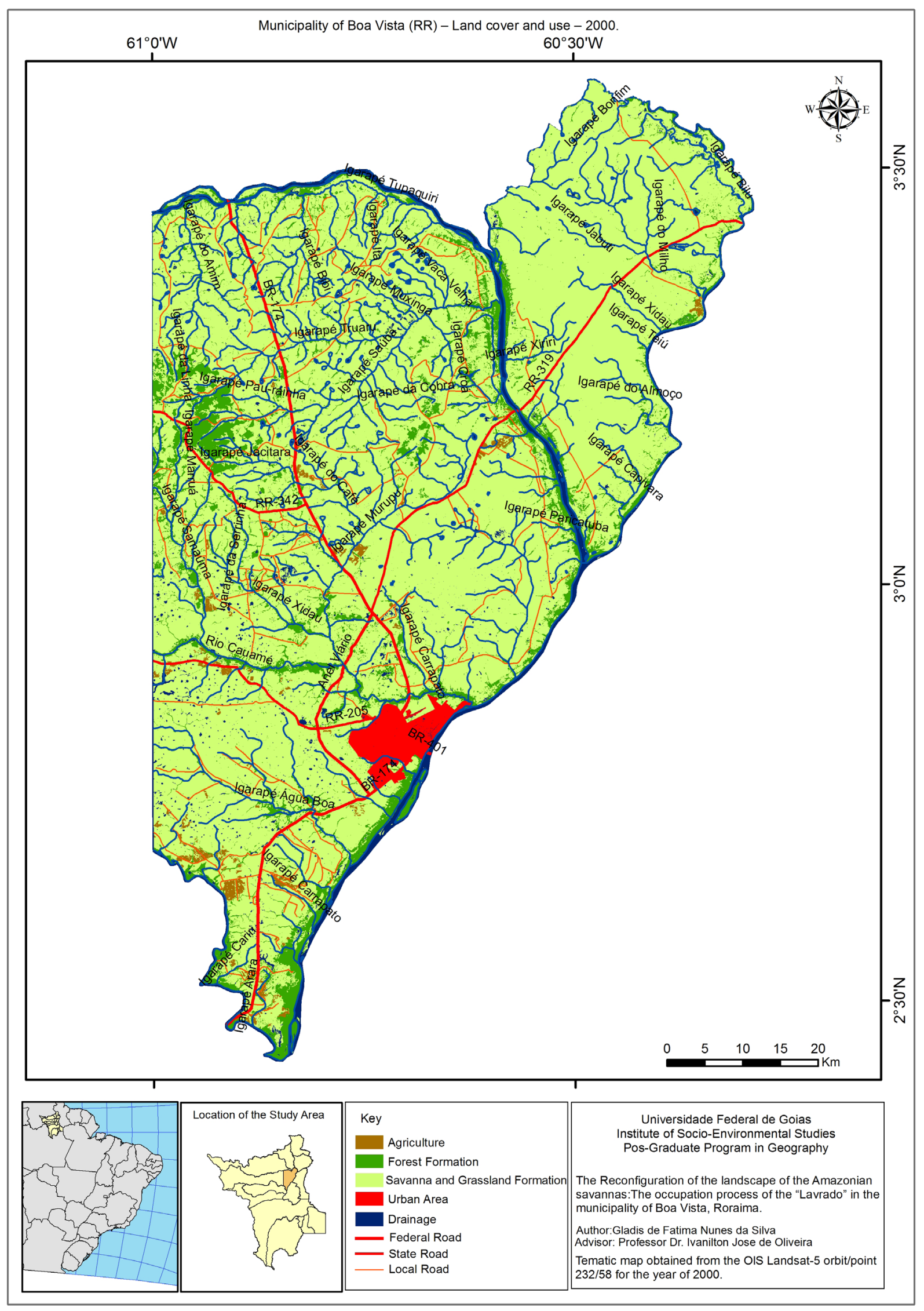

Figure 5 - Thematic map of the use and land cover of the municipality of Boa Vista (RR) - 2000 
Table 2 - Planimetry of the map of Use and land cover of the Boa Vista municipality (RR) in 2000

\begin{tabular}{|c|c|c|}
\hline CLASSES OF USE AND LAND COVER & $\operatorname{AREA}\left(\mathbf{k m}^{2}\right)$ & $\operatorname{AREA}(\%)$ \\
\hline Grassland and Savanna Formations & $4,746.0$ & 83.60 \\
\hline Forest Formation & 646.2 & 11.38 \\
\hline Agriculture & 50.9 & 0.89 \\
\hline Urban Area & 83.9 & 1.47 \\
\hline Bodies of Water & 145.9 & 2.66 \\
\hline Total & $5,672.9$ & 100,00 \\
\hline
\end{tabular}

Source: Calculation obtained in GIS.

According to data from CPRM (2002), the aquifer system Boa Vista is a free to semi-confined aquifer and has an area of approximately $14,000 \mathrm{~km} 2$ in the state, covering most of the municipality of Boa Vista. The municipality's water resources are of strategic importance for socio-economic development, as they play an important role in public and private provisions, supplying the most varied water needs for urban use, as well as industries, agricultural irrigation, and leisure activities.

Finally, the class with the lowest occurrence corresponds to the urban area of Boa Vista, which in 2000 occupied $83.9 \mathrm{~km} 2$ or $1.47 \%$ of the total area of the municipality. However, the size of the area is not related to the geographic importance given the city's immense population concentration in relation to the total state, besides the centralization of economic, educational, health, and income activities. Analyzing Boa Vista in the state urban hierarchical context, Silva (2007) points out that in order to get an idea of the relevance of this city to the region, Boa Vista becomes an urban landmark on the tri-border frontier, being a center of concentration for Roraima and for the extreme southern regions of Venezuela and Guyana (SILVA, 2007: 205).

\section{INTENSIFICATION OF LAND USE IN 2014: THE ADVANCE OF AGRICULTURE}

The land use and coverage map for 2014 (Figure 6) and its respective environmental planimetry (Table 3) showed that there was a great expansion of agricultural activity in the municipality, as well as a significant increase in the urban site of Boa Vista, in relation to 2000.

The main changes in land use and land cover were due to the expansion of areas destined for agriculture, representing an increase of almost 4 times the area occupied in relation to the year 2000. In absolute terms, the extension of crops and planted forests went from $50.9 \mathrm{~km}^{2}$ to 182.7 $\mathrm{km} 2$ (an increase of $131.8 \mathrm{~km}^{2}$ ).

Regarding rice, the area planted in 2013 corresponded to 1,200 hectares (IBGE, 2013), showing a reduction of around $25 \%$ in relation to 2000 . This decrease in planted areas occurred both in the state and in the municipality. This can be directly related to the homologation, on a continuous basis, of the Indigenous Land called Raposa Serra do Sol, since, according to IBGE (2009), for spatial planning, mainly in the region of the savannas, where the use was verified land between farmers and indigenous communities, there was a need to separate indigenous lands, communal properties, farmer's lands, and lands for private use. 


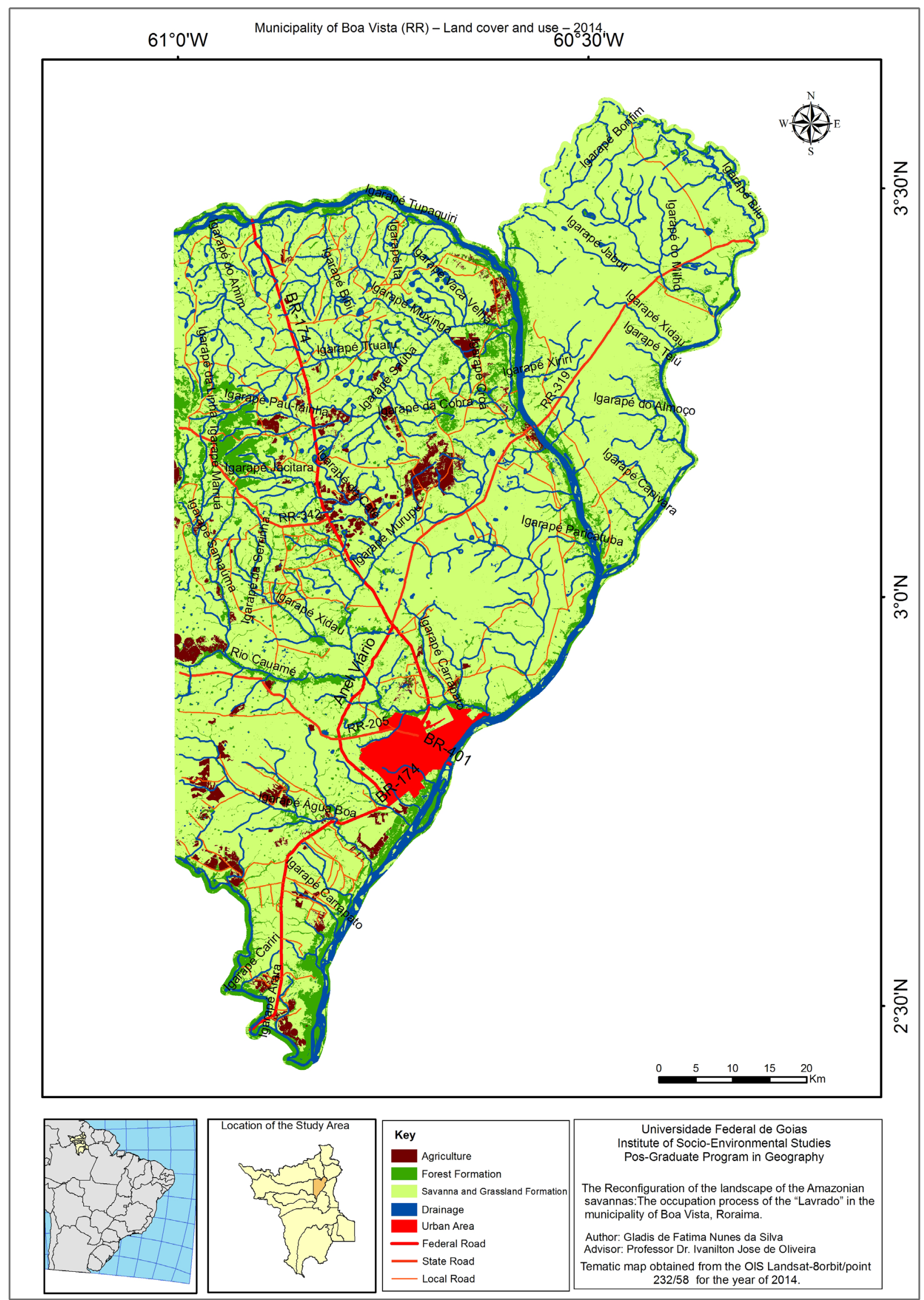

Figure 6 - Thematic map of the land cover and use of the municipality of Boa Vista (RR) - 2014 
Table 3 - Planimetry of the Land Coverage and Use Map of the Boa Vista municipality (RR) in 2014

\begin{tabular}{|c|c|c|}
\hline CLASSES OF LAND COVERAGE AND USE & $\operatorname{AREA}\left(\mathbf{k m}^{2}\right)$ & AREA $(\%)$ \\
\hline Grassland and Savanna Formations & $4,643.2$ & 81.86 \\
\hline Forest Formation & 600.9 & 10.59 \\
\hline Agriculture & 182,8 & 3.22 \\
\hline Urban Area & 102.3 & 1.80 \\
\hline Bodies of Water & 143.7 & 2.53 \\
\hline Total & $5,672.9$ & 100.00 \\
\hline
\end{tabular}

Among the factors that probably contributed to the reduction of natural vegetation cover, it was worth mentioning the planting of soybean crops, beginning in the mid-2000s within the municipality. Regarding soybean production, Gianluppi and Smiderle (2005) state that the area planted within the municipality in 2000 corresponded to only 250 hectares. The authors also argue that, in the early 2000s, the lack of land titles was a major impediment to the expansion of soybean area, as it made it unfeasible to obtain credit from the banking network (Gianluppi, SMIDERLE 2005, p. 180). According to IBGE data (2013), for the 2012/2013 crop season, there was an area equivalent to 1,100 hectares for soybean cultivation.

Among the elements considered to explain the increase in the soybean plantation area are the low land price, topography, climate, availability of water resources, logistics, especially the road, and the proximity of the capital.

Such factors are easily verified in the municipality. However, it should be noted that during the analyzed period, the state government's intentions to attract soybean producers from other Brazilian regions to the savanna areas persist due to their geographic location, physiographic characteristics, and the supply of land at low prices.

Arantes (2009, p. 212), analyzing the market value of the land in Roraima, found that in 2008 the most expensive land in the state, which included agricultural areas for rice cultivation in floodplains, in the Boa Vista region, reached the average value of BRL 1,600 / ha; while the average price of the hectare in the state was R \$ 668.00. Arantes (2009, p. 212), analyzing the market value of the land in Roraima, found that in 2008 the most expensive land in the state, which included agricultural areas for rice cultivation in floodplains, in the Boa Vista region, reached the average value of BRL 1,600 / ha; while the average price of the hectare in the state was BRL 668.00.

Another factor that certainly contributed to the expansion of agricultural areas in the municipality was the transfer of land from the Federal Government, as of 2009, to the government of the state of Roraima, which now has the right over territory and greater autonomy in regularization together with environmental and land agencies. In addition, the management and technology of productive systems also have a marked effect, since cultivated areas represented by commercial crops, especially soybean, are characterized by the incorporation of technological innovations (Figure 7) in the preparation, cultivation, and harvest, with the use of adequate capital and inputs, aiming mainly at the foreign market. 


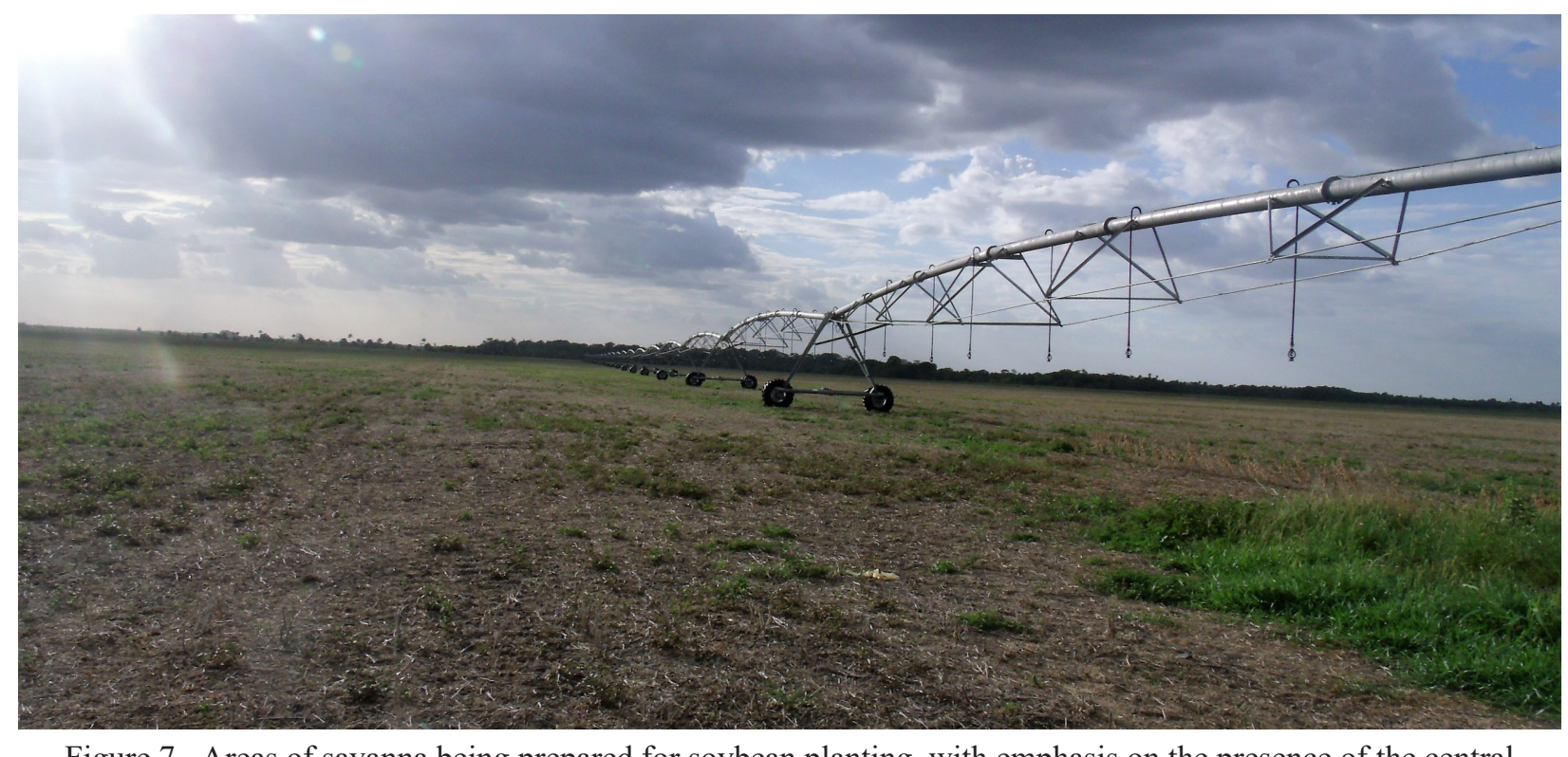

Figure 7 - Areas of savanna being prepared for soybean planting, with emphasis on the presence of the central irrigation pivot. Photographer: Frank Rocha (2014)

More recently, extensive areas of Lavrado are being devoted to forestry in the municipality. The altered areas with afforestation comprise restoration features and/or forest management, with diverse species, of tree size, especially those occupied with Acacia mangium Willd (Figure 8). These activities are concentrated in the municipality of Boa Vista, along with highway BR-174, towards Boa Vista / Pacaraima; BR-401, from Boa Vista to Bonfim; and BR-432, from Boa Vista to Cantá (IBGE, 2009).

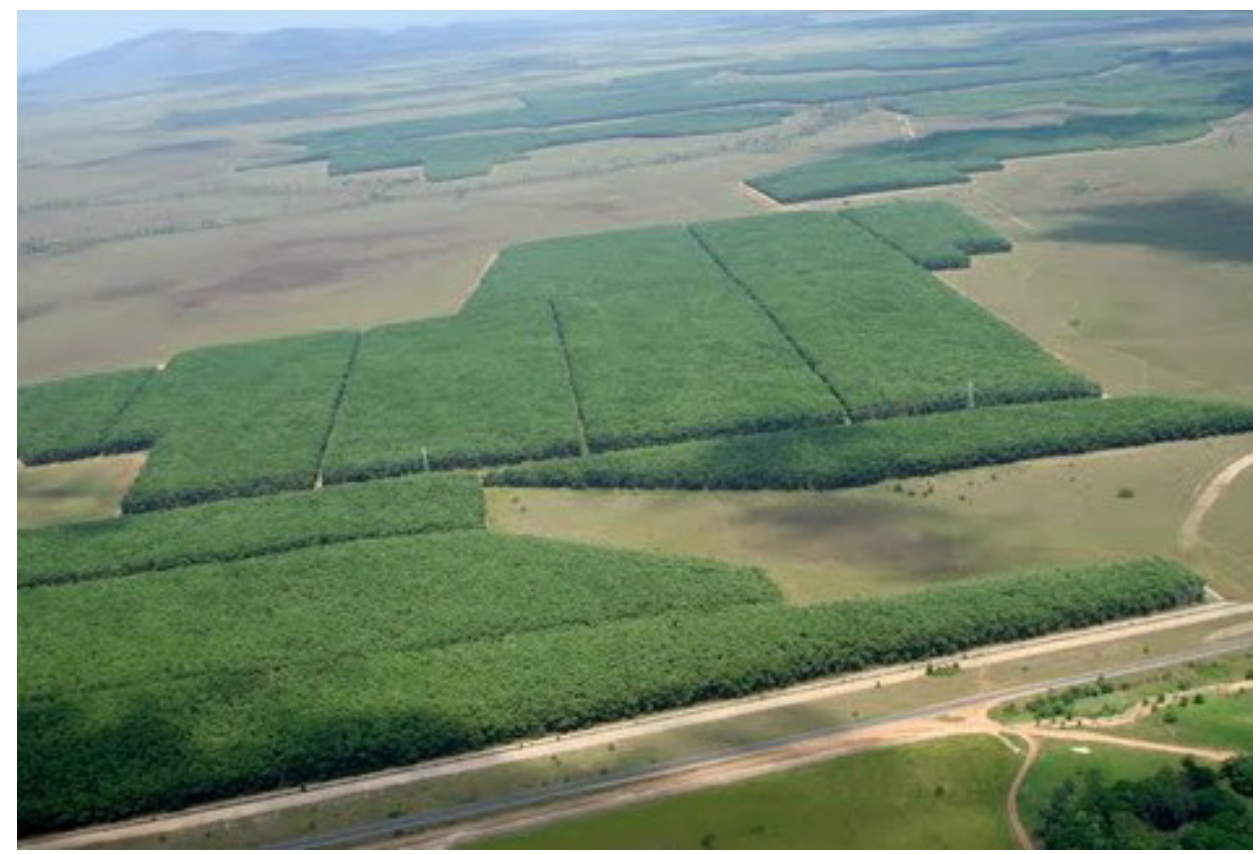

Figure 8 - Planted areas of Acacia mangium in Boa Vista (RR). Photographer: Dilamar Lewiski (2008).

According to data from the CPRM (2002), due to the expected installation of the pulp mill in Boa Vista, the planting areas were expanded and concentrated in a radius of influence marked by easy access and the lowest cost in the transportation of prime material, benefiting still of the conditions of the soils in the region of the Lavrado.

Vale Jr. et al. (2010), when evaluating the soil impacts resulting from the conversion of savannahs to Acacia mangium plantations, based on erodibility and erosion susceptibility data, the data 
maintains that the soils under Acacia plantations are, for the most part, susceptible to erosion, with a significant occurrence of laminar erosion.

Considering the perspective of a change in the use of land and land cover in the municipality, environmental monitoring was carried out to evaluate the evolution of this process in the period under analysis. Monitoring allows tracking of the evolution of environmental characteristics and phenomena by comparing successive mappings over time. Thus, this evaluation was elaborated for the agriculture class, comparing the years 2000 and 2014, considering that the changes caused by the conversion of the savannas into agricultural areas, considered here as agents modifying the landscape and the various elements that compose it, tend to compromise native vegetation, soils, and water systems, among other natural resources.

From the spatial overlap, of the agriculture class to the thematic map of land use and coverage of the municipality created for the period of 2014, it was possible to identify areas that were maintained with agriculture, the increase of areas converted to agriculture, and the new categories occupying transformed landscapes.

The result of the monitoring, shown in Figure 9, reveals where and how the expansion of agricultural activity in the municipality occurred. The area occupied by this class in 2000, which corresponded to $0.89 \%$ of the total area of the municipality, increased to $3.29 \%$. These results also demonstrate the advance of agriculture over the remnants of savannas and grassland formations. They also indicate that the spatial distribution of the agricultural areas occurred in a heterogeneous way. However, it is observed that concentration occurred in the central and southern portions of the municipality, favored probably because of the expansion of the road system. In relation to livestock, cattle raising was the main economic activity that consolidated the occupation of the municipality. However, the municipality's cattle herd showed a significant decre- ase during the analyzed period. In 2000, the cattle herd totaled 42,000 head; as of 2013, the total number of cattle in the municipality was 27,778 head (IBGE, 2013).

This decrease was mainly due to the geographical displacement of livestock, from the traditional fields and savannas to the forest areas of the southern part of the state IBGE (2009), currently, in the savanna areas the agricultural sector is consolidating, with the expansion of grain production, especially soybean cultivation. The displacement of cattle ranching towards previously deforested areas in the south of the state is also motivated by the location of indigenous lands in the savanna region. In spite of the displacement, Mourão (2008) affirms that in the areas of savannas the old systems of animal husbandry exist alongside the modern agricultural facilities with a certain level of technological application, which had its origin in the incentives of the Superintendence of Development of the Amazonia (SUDAM) granted to Roraima, in the early 1990s.

Therefore, the data reinforce the idea of a change in the dynamics of land use and land cover in the municipality of Boa Vista, from a model that was based exclusively on extensive livestock for a diversified use, including polyculture and modernized livestock farming (IBGE, 2009). As a result of these changes, the remaining vegetation cover (grassland and savanna formations), in turn, presented a reduction of area between 2000 and 2014, going from 4,746 km2 to 4,643 $\mathrm{km}^{2}$.

The forest formations, including the ombrophilous and seasonal vegetation, also showed, in the analyzed period, an area reduction of around $2.21 \%$, especially the riparian forests. Some waterways do not serve this vegetation or serve it in a discontinuous way, indicating the agricultural pressure on the areas of native vegetation, which may represent a risk to the water resources. 


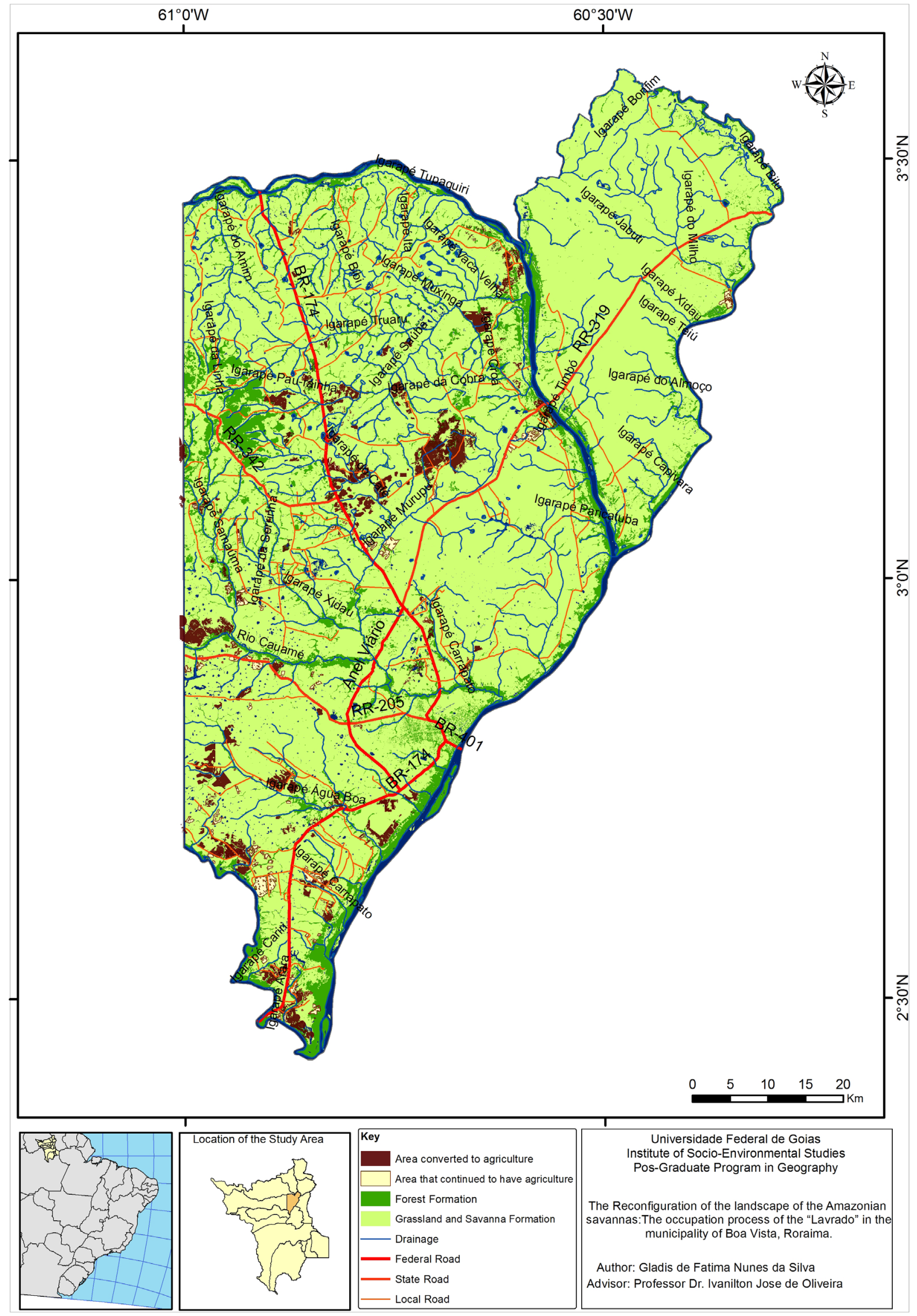

Figure 9 - Environmental monitoring for agriculture 
Finally, the urban site of Boa Vista also showed an increase of $22 \%$ in its area in the analyzed period, going from $83.9 \mathrm{~km} 2$ to $102.3 \mathrm{~km} 2$, in a continuous process of consolidated urbanization. This phenomenon reflected that the population increase registered in the state of Roraima, characterized by the population density in the municipality of Boa Vista, was concentrated mainly in the urban area. According to the IBGE demographic census (2010), Roraima had a population of 450,479 inhabitants, of which 284,313 were in Boa Vista alone, or $63.11 \%$ of the total. In the municipality, the population was already eminently urban since only $2.3 \%$ of the inhabitants lived in rural households. In this context, Silva (2007), when analyzing the population concentration in Boa Vista, highlights the migratory process as a strong driver of this system, stimulated by the arrival of migrants attracted by contests for public jobs and by the agricultural, livestock, and resulting services (Silva, 2007, 274).

It should be noted that this expansion in a disorganized way has caused a change in the urban landscape of Boa Vista, as the increasing demand for housing drives the population, especially the less favored social classes, to occupy Permanent Preservation Areas (APPs), mainly at the margins of urban watercourses and lake environments, sites without sewage collection infrastructure and treated water supply, leading to serious risks of the degradation of water systems and creating public health problems.

The Boa Vista Aquifer System (SABV) is currently responsible for $70 \%$ of the urban water supply, through a network of 102 tubular wells, under the control of the Water and Sewage Company of Roraima - CAER (SEPLAN, 2008). Wankler, Evangelista, and Sander (2012) argue that groundwater is still the most viable technical and economic alternative for supplying the suburbs of the city of Boa Vista. In the interpretation of Reis Neto et al. (2006), changes in land use, by grounding the lacustrine system of poor areas, to cede spaces for residential constructions, as well as the increase of impermeable surfaces, has caused serious ecological imbalances and contributed to a periodic increase of floods in Boa Vista.

\section{FINAL CONSIDERATIONS}

The bibliographic-documentary research and the data and techniques used proved to be efficient for the analysis of the spatial-temporal dynamics of land use and land cover of the municipality of Boa Vista (RR). Based on the interpretation of satellite images, the creation of thematic maps, and quantification in the GIS environment, it was evident that there is an intensification of the use and modification of the land cover in the municipality of Boa Vista, related to the production of grains, especially with the expansion of soybean cultivation, which has contributed to the displacement of livestock, from the traditional fields and savannahs to the forest areas of the south of the state, thus contributing to the alteration of the savannas landscapes of the municipality.

The historical process of occupation and intensification rose from the actions of the State, followed by strategic measures of the state government when guiding its actions in the strengthening of agriculture and livestock. In this setting, the areas of Lavrado became strategic to the productive process. It can be seen that, once the development model is being consolidated, it is marked by the intensified use of savannas and is materializing in space through monoculture, mainly soybean, associated with the legitimation of land concentration and intensification of mechanization. This has resulted in negative environmental impacts, similar to the occupation process that occurred in the Cerrado of Central Brazil, mainly from the 1970s.

\section{BIBLIOGRAPHIC REFERENCE}

AB'SABER, A. N. Os domínios de natureza no Brasil. São Paulo: Ateliê Editorial, 2003. 
ARANTES, E.C. Regularização Fundiária e direito de propriedade na Amazônia Legal. Porto Alegre. Dissertação (Mestrado Profissional Interinstitucional em Economia) - Universidade Federal do Rio Grande do Sul, UFRGS/PPGE, 2009. 316 f.

BARBOSA, R. I. Ocupação humana em Roraima. I. Do histórico colonial ao início do assentamento dirigido. Bol. Mus. Par. Emílio Goeldi, v. 9, n. 1, p. 123-144, 1993 a.

BARBOSA, R. I. Ocupação humana em Roraima. II. Uma revisão do equívoco da recente política de desenvolvimento e crescimento desordenado. Bol. Mus. Par. Emílio Goeldi, v. 9, n. 2, p. 177-197, 1993 b.

BARBOSA, R. I.; CAMPOS, C. Detection and geographical distribuition of clearing areas in the savannas (lavrado) of Roraima using Google Earth web tool. Journal of Geography and Regional Planning, v. 4, p. 122-136, 2011.

BARROS, N. C. C. Paisagem e tempo na Amazônia Setentrional. Recife: Ed. Universitária UFPE, 1995. BARROS, N. C. de. Memória oral \& escrita, frentes florestais e a construção do trabalho geográfico. Revista de Geografia, v. 16, n. 2, p. 61-72, maio/ago. 2009.

BRASIL. IBGE. Mapa de Biomas do Brasil. Escala 1:5.000.000. Rio de Janeiro: IBGE, 2004.

BRASIL. IBGE. Projeto Levantamento e Classificação da Cobertura e do Uso da Terra - Uso da Terra no Estado de Roraima (Relatório Técnico). Rio de Janeiro: Instituto Brasileiro de Geografia e Estatística / Diretoria de Geociências / Coordenação de Recursos Naturais e Estudos Ambientais, 2005. 94p.

BRASIL. IBGE. 2009. Produção Agrícola Municipal. Culturas Temporárias. Disponível em: $<$ http//www. sidra.ibge.gov.br>. Acesso em: março 2014.

BRASIL. IBGE. 2009. Produção Pecuária Municipal. Efetivo do Rebanho bovino. Disponível em: <http// www.sidra.ibge.gov.br>. Acesso em: março 2014.

BRASIL. IBGE. Manual Técnico da Vegetação Brasileira. 2. ed. Rio de Janeiro: IBGE, 2012. 182 p. (Manuais técnicos em geociências, ISSN 0103-9598).

CORDEIRO, A. C. C. O cultivo do arroz irrigado em Roraima. In: BARBOSA, R. I. et al. Savanas de Roraima. Boa Vista: Femact-RR, 2005.

CORDEIRO, A. C. C.; SUHRE, E; MEDEIROS, R. D.; VILARINHO, A. A. Sistemas de cultivo e manejo de água na produção de diferentes genótipos de arroz em várzea, no estado de Roraima. Pesq. Agropec. Trop., Goiânia, v. 40, n. 3, p. 362-369, 2010.

CORADIN, L. Aproveitamento dos campos nativos do território Federal de Roraima para a pecuária. Anais... Congresso Nacional de Botânica. Plantas Forrageiras. Campo Grande, 1979. p. 25-48.

COSTA, W. M. da. O Estado e as políticas territoriais no Brasil. 7. ed. São Paulo: Contexto, 1997. 83 p.

CPRM. Companhia de Pesquisas de Recursos Minerais - Serviço Geológico do Brasil 2002. Zoneamento Ecológico-Econômico da Região Central do Estado de Roraima. Rio de Janeiro: CPRM, 2002. 1 CD-ROM. DINIZ, A. M. A. A evolução da fronteira em Roraima o caso das Confianças I, II e III. In: ALVES, C. L. E. (org.). Formação do Espaço Amazônico e Relações Fronteiriças. Boa Vista: Ed. Universidade Federal de Roraima, 1998. p.150-179.

DINIZ, A. M. A. Frontier evolution and mobility in volatile frontier settlements of the Brazilian Amazon. 2002. Tese (Doutorado) - Arizona State University.

DINIZ, A.M.A; SANTOS, R.O. Impactos sócio-ambientais na Fronteira Agrícola de Roraima. Encontro Nacional de Estudos Populacionais, 14. Caxambú-MG. Anais... Caxambú-MG: ABEP, 2004.

EMBRAPA. Centro Nacional de Pesquisa de Solo. Sistema brasileiro de classificação de solo: 4a aproximação / Centro Nacional de Pesquisa do Solo - Rio de Janeiro, 1999. 169 p.

GIANLUPPI, D.; GIANLUPPI, V.; SMIDERLE, O. Produção de pastagens no cerrado de Roraima. Boa Vista: Embrapa Roraima, 2001. 4p. (Comunicado Técnico, 14).

GIANLUPPI, D.; SMIDERLE, O. J. O cultivo da soja nos Cerrados de Roraima. In: Barbosa, R. I.; XAUD, H.A.M.; COSTA E SOUZA, J.M. (Org.) Savanas de Roraima. Boa Vista: FEMACT, 2005. p.177-182.

MOURÃO G. M. N. Roraima no Contexto Agrário. In: SILVA, P. R. de F.; OLIVEIRA. R. S. (orgs.) Roraima 20 anos. Boa vista, UFRRR, 2008.

SANAIOTTI, T. M.; MARTINELLI, L. A.; VICTORIA, R. L.; TRUMBORE S. E.; CAMARGO, P. B. Past 
vegetation changes in Amazon savanas determined using carbon isotopes of soil organic matter. Biotropica, v. 34, p. 2-16, 2002.

SEPLAN - Secretaria de Estado de Planejamento e Desenvolvimento de Roraima. Roraima. Boa Vista: SEPLAN-RR, 2008.

SILVA, P. R. de F. Dinâmica territorial urbana de Roraima. 2007. Tese (Doutorado em Geografia) - Programa de Pós-Graduação em Geografia Humana. Departamento de Filosofia, Letras e Ciências Humanas da Universidade de São Paulo, São Paulo. 329 fls.

USO DA TERRA do estado de Roraima: relatório técnico. Rio de Janeiro: IBGE, 2009. Disponível em: $<$ http://geoftp.ibge.gov.br/documentos/recursosnaturais/usodaterra/usoterra_RR.pdf $>$. Acesso em: julho 2011. VALE JUNIOR, J. F.; SCHAEFER, C.E.R.G. Solos sob savanas de Roraima. Boa Vista: Ioris, 2010.

XAVIER DA SILVA, J.; ZAIDAN, R. T.(Org.).Geoprocessamento \& meio ambiente. Rio de Janeiro: Bertrand Brasil, 2011.

XAVIER-DA-SILVA, J.; CARVALHO FILHO, L. M. Sistemas de Informação Geográfica: uma proposta metodológica. Anais... Conferência Latino Americana sobre Sistemas de Informação Geográfica, 4; Simpósio Brasileiro de Geoprocessamento, 2. São Paulo. Anais... São Paulo: USP, 1993. p. 609-628.

WALTER, B.M.T.; CARVALHO, A.M.; RIBEIRO, J.F. As principais fitofisionomias do bioma Cerrado. In: SANO, S, M.; ALMEIDA, S.P.; RIBEIRO, J.F. (Ed.). Cerrado. Brasília-DF: Embrapa Informação Tecnológica, 2008. p. 19-45.

WANKLER, F.L.; EVANGELISTA, R.A.O; SANDER, C. Sistema aquífero Boa Vista: "estado de arte" do conhecimento e perspectivas. ACTA Geográfica, Boa Vista, v.6, n.12, p. 21-39, maio/ago. 2012. 